Document downloaded from:

http://hdl.handle.net/10251/148009

This paper must be cited as:

Ciavatta, ML.; López-Gresa, MP.; Gavagnin, M.; Nicoletti, R.; Manzo, E.; Mollo, E.; Guo, Y.... (2008). Cytosporin-related compounds from the marine-derived fungus Eutypella scoparia. Tetrahedron. 64(22):5365-5369. https://doi.org/10.1016/j.tet.2008.03.016

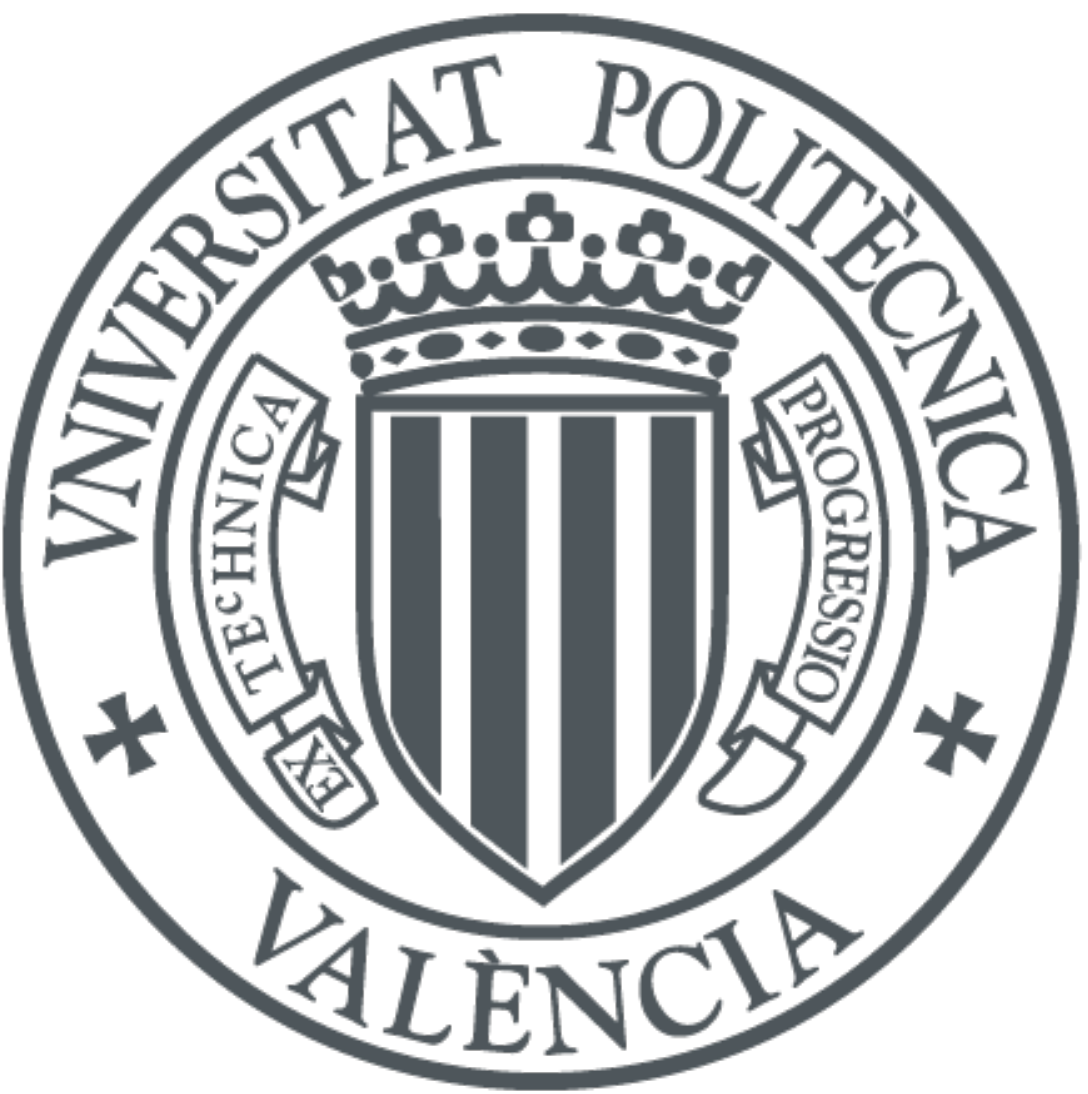

The final publication is available at

https://doi.org/10.1016/j.tet.2008.03.016

Copyright Elsevier

Additional Information 


\section{Cytosporin-related compounds}

\section{from the marine-derived fungus Eutypella scoparia}

\footnotetext{
Maria Letizia Ciavatta, ${ }^{\mathrm{a}}$ M. Pilar Lopez-Gresa, ${ }^{\mathrm{b}}$ Margherita Gavagnin, ${ }^{\mathrm{a}}$ Rosario Nicoletti, ${ }^{\mathrm{c}}$ Emiliano Manzo, ${ }^{\mathrm{a}}$ Ernesto Mollo, ${ }^{\mathrm{a}}$ Yue-Wei Guo, ${ }^{\mathrm{d}}$ and Guido Cimino ${ }^{\mathrm{a}}$

${ }^{a}$ Istituto di Chimica Biomolecolare, C.N.R., Pozzuoli, 80078, Italy ${ }^{b}$ Centro de Ecología Química Agrícola, Universidad Politécnica de Valencia, Campus de Vera, Edificio 6C, 46022 Valencia, Spain, c Istituto Sperimentale per il Tabacco, C.R.A., Scafati, 84018, Italy

${ }^{\mathrm{d}}$ State Key Laboratory of Drug Research, Institute of Materia Medica Shanghai, Institutes for Biological Sciences, Chinese Acadmy of Sciences, 201203, Shanghai, China
}

*Corresponding author: Phone: +390818675243; Fax: +390818041770;

E-mail: lciavatta@icmib.na.cnr.it 
Abstract - Chemical investigation of the culture broth of the fungus Eutypella scoparia ICBOBX, isolated from the marine pulmonate mollusc Onchidium sp., led to the finding of novel compounds 1 and 2, structurally related to angiotensin II binding inhibitors cytosporins, along with unrelated known nitrogen metabolites (compounds 3-5). The structure and the relative stereochemistry of the novel metabolites were assigned mainly by a detailed analysis of twodimensional NMR techniques whereas the absolute stereochemistry was proposed by modified Mosher's method. Compound 2 contains an unusual cyclic carbonate functionality that is rare among natural products.

Keywords: Hexahydrobenzopyrane derivatives; Cytosporins; Marine fungus; Eutypella scoparia; Carbonate; NMR; Mosher method.

\section{Introduction}

Marine micro-organisms such as bacteria and fungi inhabit every environment of the sea and are rich sources of pharmacologically active compounds. ${ }^{1}$ The interest towards marine micro-organisms has grown in the last years due to the possibility to get abundant biomass by in vitro culturing and consequently large amount of produced secondary metabolites. Among marine micro-organisms, fungi have shown great potential due to the high structural diversity of natural products biosynthesized. ${ }^{2}$ The majority of the chemical data reported in the literature refer to fungi derived from sponges and algae whereas only a few papers deal with the secondary metabolites of mollusc-derived fungi. ${ }^{2,3}$ In particular, an unique gastropod mollusc, the sea hare Aplysia kurodai, has been reported as source of fungal isolates producing compounds with antitumor and cell adhesion inhibition activities. ${ }^{4}$

In the course of our investigation on marine molluscs ${ }^{5}$ we analysed the pulmonate gastropod Onchidium sp., collected in the intertidal area of Hainan (South China Sea), that was found to be characterised by a series of unprecedented polypropionates. ${ }^{6}$ Subsequently we also examined the secondary metabolites produced in the culture broth of the fungus Eutypella scoparia ICB-OBX, which was isolated from the external part of the mollusc. This study led to two novel molecules $\mathbf{1}$ and $\mathbf{2}$, along with known nitrogen compounds 3-5, previously reported from fungi and natural sources. ${ }^{7,8}$ Compounds $\mathbf{1}$ and $\mathbf{2}$ are structurally 
related to cytosporins A-C, isolated from an endophytic strain of the taxonomically related fungus Cytospora and showed to be angiotensin II binding inhibitors. ${ }^{9}$

In this paper, the chemical characterization of the new metabolites that we named cytosporin D (1) and cytosporin E (2) is described.

\section{Results and Discussion}

The EtOAc extract of the culture broth was analyzed by TLC chromatography by using different eluent systems. The secondary metabolite pattern was found to be dominated by the presence of a main spot at $\mathrm{R}_{f} 0.6\left(\mathrm{CHCl}_{3} / \mathrm{CH}_{3} \mathrm{OH}\right.$, 95:5) along with a series of minor components. The extract was purified by silica-gel column chromatography (chloroform/methanol gradient) to give two main fractions containing the compounds of interest. The two fractions were further purified by silica-gel column ( $n$-hexane/EtOAc gradient) to obtain compounds $1(5.1 \mathrm{mg})$ and $2(9.0 \mathrm{mg})$, along with the main metabolite phenochalasin B $(\mathbf{3}, 28.3 \mathrm{mg})$, from the more polar fraction, whereas cyclo-(D)-Pro-(D)-Leu (4, $3.9 \mathrm{mg})$ and cyclo-(D)-Pro-(D)-Phe $(\mathbf{5}, 2.0 \mathrm{mg})$ were recovered from the less polar fraction.

The already known compounds 3-5 were identified by comparing their spectral data $\left({ }^{1} \mathrm{H}\right.$ and ${ }^{13} \mathrm{C}$ NMR, MS and $[\alpha]_{\mathrm{D}}$ ) with the literature. ${ }^{7,8}$ The new molecules $\mathbf{1}$ and $\mathbf{2}$ were characterized as below described.

Cytosporin D (1) showed the molecular formula $\mathrm{C}_{19} \mathrm{H}_{30} \mathrm{O}_{5}$ as deduced by the sodiatedmolecular peak at $\mathrm{m} / \mathrm{z} 361.1988$ in the HR-ESIMS spectrum indicating five degrees of unsaturation. The ${ }^{13} \mathrm{C}$-NMR spectrum disclosed seven $\mathrm{sp}^{3}$ carbons between $\delta 57.4$ and $\delta 77.7$ that were assigned to carbons linked to oxygen (one primary, four secondary and two tertiary), eight $\mathrm{sp}^{3}$ high-field resonating signals between $\delta 14.3$ and $\delta 36.5$, and four $\mathrm{sp}^{2}$ carbons at $\delta 126.7$ (d, C-14), 130.7 (s, C-8), 133.5 (s, C-9), and 135.7 (d, C-15) indicating two double bonds. The remaining unsaturations required by the formula were thus attributed to three rings. The ${ }^{1} \mathrm{H}-\mathrm{NMR}$ spectrum showed two olefinic signals at $\delta 6.48(\mathrm{H}-14)$ and 6.15 (H-15), which were attributed to the protons of a disubstituted double bond, four methines and a methylene linked to oxygenated carbons at $\delta 4.65(\mathrm{H}-7), 4.53(\mathrm{H}-10), 4.41(\mathrm{H}-13 \mathrm{a})$, $4.08(\mathrm{H}-13 \mathrm{~b}), 3.68(\mathrm{H}-3)$ and $3.29(\mathrm{H}-6)$, two methyl singlets at $\delta 1.30\left(\mathrm{H}_{3}-11\right)$ and $1.25\left(\mathrm{H}_{3^{-}}\right.$ 
12), and a methyl triplet at $\delta 0.95\left(\mathrm{H}_{3}-20\right)$. A series of multiplet signals due to five methylenes completed the spectrum (Table 1). Analysis of ${ }^{1} \mathrm{H}-{ }^{1} \mathrm{H}$ COSY spectrum clearly defined some spin systems (Fig. 1): the chain C-14/C-20 ( $\delta 6.48, d,(15.8), H-14 ; \delta 6.15$, dt, (7.0, 15.8), H-15; $\delta 2.23$, td, (7.0), $\mathrm{H}_{2}-16 ; \delta 1.50, \mathrm{~m}, \mathrm{H}_{2}-17 ; \delta 1.40, \mathrm{~m}, \mathrm{H}_{2}-18 ; \delta 1.38, \mathrm{~m}, \mathrm{H}_{2}-$ 19 and $\delta 0.95, \mathrm{t},(6.6), \mathrm{H}_{3}-20$, fragment a), an isolated oxygenated methylene $(\delta 4.41, \mathrm{~d}$, (12.0), H-13a and $\delta 4.08, \mathrm{~d},(12.0), \mathrm{H}-13 \mathrm{~b}$, fragment b), two vicinal oxygenated methines ( $\delta$ 4.65 , br s, H-7 and $\delta 3.29$, br s, H-6, fragment c), and an ABX system constituted by a methylene linked a carbinolic proton $(\delta 2.32$, t, (12.0), H-4ax, $\delta 1.70$, dd, $(4.8,12.0), \mathrm{H}-4 \mathrm{eq}$ and $\delta 3.68$,dd, $(4.8,12.0), \mathrm{H}-3$, fragment d). Long-range experiments aided us to link these partial structures. In particular, the signal at $\delta 77.7$ (C-2) had diagnostic correlations with the methyls at $\delta 1.30\left(\mathrm{H}_{3}-11\right)$ and $1.25\left(\mathrm{H}_{3}-12\right)$ and with the protons at $\delta 3.68(\mathrm{H}-3)$ and $\delta 4.53$ (H-10). The signal at $\delta 57.4(\mathrm{C}-5)$ had cross-peaks with the protons at $\delta 3.29(\mathrm{H}-6), \delta 4.65$ $(\mathrm{H}-7)$, and the methylene at $\delta 2.32$ and $1.70\left(\mathrm{H}_{2}-4\right)$ whereas the signal at $\delta 133.5(\mathrm{C}-9)$ showed correlations with methines at $\delta 4.53(\mathrm{H}-10), \delta 4.65(\mathrm{H}-7)$, and $\delta 6.15(\mathrm{H}-15)$, as well as with the isolated methylene at $\delta 4.41$ and $4.08\left(\mathrm{H}_{2}-13\right)$. These data were consistent with a tricyclic structure containing an hexahydrobenzopyrane moiety fused with an oxirane ring as reported in formula $\mathbf{1}$. To confirm the suggested gross structure, a sample of compound $\mathbf{1}$ was acetylated by $\mathrm{Ac}_{2} \mathrm{O} / \mathrm{DMPA}$ in $\mathrm{CH}_{2} \mathrm{Cl}_{2}$ leading to the triacetyl derivative 1a, which was analysed by ${ }^{1} \mathrm{H}-\mathrm{NMR}$. Diagnostic acylation shifts were observed for $\mathrm{H}-3, \mathrm{H}-7$ and $\mathrm{H}_{2}-13$ (see Experimental Section) in agreement with the proposed structure. Compound $\mathbf{1}$ exhibits a carbon skeleton characterized by a polyketide moiety and a terpenoid part, reported only previously for cytosporins A-C [e.g. cytosporin C (6)], which were isolated some years ago from an endophytic Cytospora sp. ${ }^{9}$ The full structure characterization of cytosporins A-C has never been published whereas their pharmacological properties in the inhibition of angiotensin II binding have been described. ${ }^{9,10}$ The structure proposed for compound $\mathbf{6}^{9}$ displayed strong analogies with compound $\mathbf{1}$ differing only in the length of the reduced chain at $\mathrm{C}-8$ and in the presence of the aldehyde function at C-9 replacing of the hydroxyl methylene group. However, the unassigned ${ }^{13} \mathrm{C}-\mathrm{NMR}$ data reported for $\mathbf{6}$ match almost completely with those of compound 1. Our tentative assignment (see Experimental Section) 
displayed the main difference for the C-7 carbon value. This anomaly could be justified by a different orientation of the hydroxy group at C-7 that was not determined for cytosporin $\mathrm{C}$ (6).

The relative stereochemistry of cytosporin D (1) was only partially defined by NMR analysis. The hydroxyl at C-3 was equatorial as inferred by the multiplicity of the carbinolic proton $\mathrm{H}$ $3(\mathrm{dd}, J=12.0$ and $4.8 \mathrm{~Hz}$ ) consistently with an axial orientation. A diagnostic NOE effect was observed between $\mathrm{H}-10(\delta 4.53)$ and the axial methyl $\mathrm{H}_{3}-11(\delta 1.30 ; \delta 16.4, \mathrm{C}-11)$ supporting the axial orientation of $\mathrm{H}-10$. The other steric effects observed in a series of NOE difference experiments were not useful to establish the orientation of both the epoxide ring at C-5/C-6 and the hydroxyl group at C-7 of cytosporin-D (1) that remained undetermined. Further data were obtained by analysis of the spectral data of the co-occurring cytosporin-E (2).

The molecular formula of compound 2 was $\mathrm{C}_{20} \mathrm{H}_{30} \mathrm{O}_{7}$ as deduced from the sodiated peak at $m / z 405.1883$ in the HRESIMS spectrum, implying six degrees of unsaturation and an additional $\mathrm{CO}_{2}$ unit with respect to $\mathbf{1}$. The ${ }^{1} \mathrm{H}-\mathrm{NMR}$ spectrum of $\mathbf{2}$ showed strong analogies with that of cytosporin-D (1) (Table 1) indicating the presence of the same hexahydrobenzopyrane skeleton with an alkyl chain at C-8. In particular, the major differences were observed for H-6 and H-7 protons resonating in compound 2 at $\delta 4.78$ (dd, $J=7.9$ and $1.7 \mathrm{~Hz})$ and $\delta 5.58(\mathrm{~d}, J=7.9 \mathrm{~Hz})$, respectively, whereas in compound 1 these signals resonated at $\delta 3.29$ (br s) and $\delta 4.65$ (br s) (Table 1). This was consistent with a different substitution pattern in this part of the molecule. The presence of a carbonate moiety in compound 2 was suggested by a strong IR absorption at $1650 \mathrm{~cm}^{-1}$ as well as by a diagnostic ${ }^{13} \mathrm{C}$ NMR signal at $\delta 156.0$. The ${ }^{13} \mathrm{C}-\mathrm{NMR}$ spectrum of $\mathbf{2}$ showed in addition the expected four $\mathrm{sp}^{2}$ carbons, seven $\mathrm{sp}^{3}$ carbons linked to oxygen and eight $\mathrm{sp}^{3}$ high-field resonating signals, similar to those of $\mathbf{1}$, accounting for 20 carbons as required by mass formula (Table 1).

The ${ }^{1} \mathrm{H}-{ }^{1} \mathrm{H}$ COSY spectrum of $\mathbf{2}$ revealed the presence of the same spin systems as $\mathbf{1}$ (partial structures a-d, Fig. 1), that were connected by HMBC analysis to give the same carbon framework. In particular, diagnostic HMBC correlations between C-21 ( $\delta$ 156.0) and both protons H-6 ( $\delta 4.78)$ and $\mathrm{H}-7$ ( $\delta 5.58)$ led us to link the carbonyl to both oxygen atoms at C-6 and C-7 obtaining a cyclic carbonate moiety, as reported in formula 2. Such functionality, 
which is quite rare in nature, has been reported for metabolites [e.g. phomoxin C (7)] of fungi of genera Phoma ${ }^{11}$ and Eupenicillium. ${ }^{12}$

A sample of compound $\mathbf{2}$ was submitted to acetylation giving the diacetate derivative $\mathbf{2 a}$, which was characterized by ${ }^{1} \mathrm{H}$ NMR and mass spectroscopy. Diagnostic acylation shifts were observed for $\mathrm{H}-3$ and $\mathrm{H}_{2}-13$ (see Experimental Section) in agreement with the proposed structure.

The relative stereochemistry of cytosporin-E (2) was determined by analysis of both ${ }^{1} \mathrm{H}-{ }^{1} \mathrm{H}$ coupling constants and n.O.e. difference experiments. Analogously with 1, the multiplicity of the carbinolic proton $\mathrm{H}-3(\delta 4.05, \mathrm{dd}, J=11.8$ and $4.8 \mathrm{~Hz})$ indicated the equatorial orientation of the hydroxyl group at C-3 whereas significant n.O.e. interactions between H-10 ( $\delta 4.25)$ and the axial methyl $\mathrm{H}_{3}-11(\delta 1.30)$ supported the axial orientation of $\mathrm{H}-10$. The cis-junction of the hexahydrobenzopyrane moiety of cytosporin-E (2) was determined by analysing a NOESY experiment carried out on the acetyl derivative 2a, with the tertiary $-\mathrm{OH}$ being the unique hydroxyl group free. A clear cross peak between $\mathrm{H}-10(\delta 4.25)$ and $\mathrm{OH}-5(\delta 5.60)$ was observed in the spectrum recorded in DMSO- $\mathrm{d}_{6}$ (see Experimental Section) thus inferring the same orientation of the angular substituents at C-5 and C-10. Finally, the irradiation of H-6 ( $\delta$ 4.78) caused the enhancement of both $\mathrm{H}-7$ ( $\delta 5.58)$ and $\mathrm{H}-4 e q(\delta 2.30)$ signals indicating that the carbonate cycle was trans-oriented with respect to the angular OH-5. Accordingly, a strong n.O.e. effect was observed between H-15 ( $\delta$ 6.08) and H-7 $(\delta 5.58)$.

Once the relative stereochemistry of cytosporin-E (2) was established, a possible correlation between the two co-occurring cytosporins was evaluated. From a biogenetic point of view, compound $\mathbf{2}$ could be considered as derived from compound $\mathbf{1}$. In fact, it should be formed by the attack of a carbonate ion at C- 6 of the oxirane ring of compound $\mathbf{1}$ by the less-hindered face. The esterification of the carbonate unit by the vicinal hydroxyl at C-7 should give the closure of the ring leading to cytosporin-E (2). This implies that the relative stereochemistry at C-5, C-6 and C-7 of cytosporin-D (1) should be that reported, with the 5,10 cis-junction and the hydroxyl group at C-7 trans-oriented with respect to the oxirane ring.

Finally, the absolute stereochemistry of cytosporins was determined by applying the modified Mosher's method $^{13}$ on more stable cytosporin-D (1). After protection of the primary hydroxyl group at C-13 with DMT (See Experimental Section), 1b was reacted with (-)- $R$ - and (+)-S- 
MTPA chlorides to obtain $S$-ester (1c) and $R$-ester (1d), respectively. The $\Delta \delta$ values $\left(\Delta_{S}-\Delta_{R}\right)$ observed for the signals of protons nearby the hydroxyl group at C-3 and C-7 (see Table 2) indicated the $S$ and the $R$ configuration respectively, as reported in formula.

Cytosporin-D (1) and -E (2) were tested in antimicrobial assays against S. aureus, E. coli and C. albicans. No inhibitory activity was observed for the two molecules.

In conclusion, two new molecules have been isolated from the marine-derived fungus Eutypella scoparia. This species, which has been reported from many and diverse environments ranging from soil in Antarctica ${ }^{14}$ to tropical forests of Australia ${ }^{15}$ and Thailand, ${ }^{16}$ was isolated here for the first time from a marine source. However, this is not surprising because other closely related fungi (e.g. Cytospora) mostly known in association with woody plants have been also reported from marine invertebrates, in accordance with the suggestion that fungi have the capability of adapting to harsh environment.

\section{Experimental}

\subsection{General experimental procedure}

Silica-gel chromatography was performed using pre-coated Merck $\mathrm{F}_{254}$ plates and Merck Kieselgel 60 powder. Optical rotations were measured on a Jasco DIP 370 digital polarimeter. IR spectra were recorded on a Biorad FTS 155 FT-IR spectrophotometer. NMR experiments were recorded at ICB-NMR Service Centre. 1D and 2D NMR spectra were acquired in $\mathrm{CD}_{3} \mathrm{OD}$ ( $\delta$ values are reported referred to $\mathrm{CD}_{3} \mathrm{OD}$ at $3.34 \mathrm{ppm}$ ) on a Bruker DRX-600 operating at $600 \mathrm{MHz}$, using an inverse TCI CryoProbe fitted with a gradient along the Zaxis. ${ }^{13} \mathrm{C}$ NMR were recorded on a Bruker DPX-300 operating at $300 \mathrm{MHz}(\delta$ values are reported to $\mathrm{CD}_{3} \mathrm{OD}, 49.0 \mathrm{ppm}$ ) using a dual probe. High resolution ESIMS were performed on a Micromass Q-TOF Micro ${ }^{\text {TM }}$ coupled with a HPLC Waters Alliance 2695. The instrument was calibrated by using a PEG mixture from 200 to 1000 MW (resolution specification 5000 FWHM, deviation <5 ppm RMS in the presence of a known lock mass).

\subsection{Fungal material and fermentation}


Isolate ICB-OBX was recovered from the surface of pulmonate Onchidium sp. collected on the beach of the Hainan island (South China Sea), during december 2005. On the basis of ITS sequence data it was identified as E. scoparia by the Centraalbureau voor Schimmelcultures (CBS, Utrecht, the Netherlands).

The fungus E. scoparia ICB-OBX was grown on malt extract agar (MEA) at $28^{\circ} \mathrm{C}$ for a week. After a week of cultivation the mycelial plugs were cut by a cork borer and inoculated into $500 \mathrm{~mL}$ Erlenmeyer flasks containg $500 \mathrm{~mL}$ of malt extract broth (MEB), prepared with artificial seawater. This fermentation was performed at $28^{\circ} \mathrm{C}$, without shaking, for 30 days, in a total volume of $4 \mathrm{~L}$.

\subsection{Extraction and isolation}

After incubation the mycelium was removed from the culture broth by filtration. Then, the broth $(4 \mathrm{~L})$ was extracted with ethyl acetate four times $(400 \mathrm{~mL} \mathrm{x} \mathrm{4).} \mathrm{The} \mathrm{resulting} \mathrm{organic}$ extract was evaporated under vacuum to give a brown oil (400 mg) and partitioned by column chromatography on silica gel using stepwise gradient elution from $\mathrm{CHCl}_{3}$ and increasing amounts of $\mathrm{CH}_{3} \mathrm{OH}$ to give nine fractions, two of which containing compounds $\mathbf{1 - 5}$. The less polar fraction was further purified on silica gel column ( $n$-Hexane-EtOAc gradient) to obtain cyclo-(D)-Pro-(D)-Leu (4, $3.9 \mathrm{mg}$ ) and cyclo-(D)-Pro-(D)-Phe (5, $2.0 \mathrm{mg}$ ). The more polar fraction was purified on silica gel column ( $n$-Hexane-EtOAc gradient) to give phenochalasin B $(3,28.3 \mathrm{mg})$ and cytosporin $\mathrm{D}(\mathbf{1}, 5.1 \mathrm{mg})$ and cytosporin $\mathrm{E}(\mathbf{2}, 9.0 \mathrm{mg})$, in order of polarity.

Cytosporin D (1): pale yellow oil; $[\alpha]_{\mathrm{D}}-3.02$ (c $\left.0.5, \mathrm{CH}_{3} \mathrm{OH}\right)$; IR ( $\mathrm{KBr}$, liquid film) 3426 (br), 2928, 1792, 1507, $1248 \mathrm{~cm}^{-1}$; HRESIMS: found 361.1988 (361.1991 calculated for $\left.\mathrm{C}_{19} \mathrm{H}_{30} \mathrm{O}_{5} \mathrm{Na}\right) ;{ }^{1} \mathrm{H}$ - and ${ }^{13} \mathrm{C}-\mathrm{NMR}$ in $\mathrm{CD}_{3} \mathrm{OD}$ see Table 1 .

Cytosporin E (2): pale yellow oil; $[\alpha]_{\mathrm{D}}+59.9$ (c 0.29, $\left.\mathrm{CH}_{3} \mathrm{OH}\right) ; \mathrm{IR}(\mathrm{KBr}$, liquid film) 3339 (br), 2936, 1792, 1651, 1462, 1375, $1032 \mathrm{~cm}^{-1}$; HRESIMS: found 405.1883 (405.1889 calculated for $\mathrm{C}_{20} \mathrm{H}_{30} \mathrm{O}_{7} \mathrm{Na}$ ); ${ }^{1} \mathrm{H}$ - and ${ }^{13} \mathrm{C}$-NMR data in $\mathrm{CD}_{3} \mathrm{OD}$ see Table 1 . 
${ }^{1} \mathrm{H}$ - and ${ }^{13} \mathrm{C}-\mathrm{NMR}$ data in DMSO-d $\mathrm{d}_{6}(\delta$ in ppm, $J$ in $\mathrm{Hz}): 3.75(\mathrm{H}-3, \mathrm{~m}), 2.10(\mathrm{H}-4 \mathrm{eq}$, dd, 12.8, 5.7), 1.74 (H-4ax, t, 12.8), 4.70 (H-6, d, 8.0), 5.52 (H-7, d, 8.0), 4.08 (H-10, s), 1.13 $\left(\mathrm{H}_{3}-11, \mathrm{~s}\right), 1.06\left(\mathrm{H}_{3}-12, \mathrm{~s}\right), 4.28$ (H-13a, dd,12.7, 4.4), 3.92 (H-13b, dd, 12.7, 6.0), 6.46 (H-14, d, 15.8), 5.88, (H-15, m), $2.15\left(\mathrm{H}_{2}-16, \mathrm{~m}\right), 1.45\left(\mathrm{H}_{2}-17, \mathrm{~m}\right), 1.41\left(\mathrm{H}_{2}-18, \mathrm{~m}\right), 1.30\left(\mathrm{H}_{2}-19, \mathrm{~m}\right)$, $0.88\left(\mathrm{H}_{3}-20, \mathrm{t}, 7.0\right), 4.84(\mathrm{OH}-3, \mathrm{~d}, 4.8), 4.70(\mathrm{OH}-13$, br t, 5.3), $5.28(\mathrm{OH}-5$, br s); 76.0 (C-2, C), $69.2(\mathrm{C}-3, \mathrm{CH}), 41.3\left(\mathrm{C}-4, \mathrm{CH}_{2}\right), 67.0(\mathrm{C}-5, \mathrm{C}), 79.3(\mathrm{C}-6, \mathrm{CH}), 73.5(\mathrm{C}-7, \mathrm{CH}), 136.5$ (C-8, C), 127.5 (C-9, C), $68.1(\mathrm{C}-10, \mathrm{CH}), 16.3\left(\mathrm{C}-11, \mathrm{CH}_{3}\right), 28.0\left(\mathrm{C}-12, \mathrm{CH}_{3}\right), 58.5$ (C-13, $\left.\mathrm{CH}_{2}\right), 125.0(\mathrm{C}-14, \mathrm{CH}), 133.0(\mathrm{C}-15, \mathrm{CH}), 34.0\left(\mathrm{C}-16, \mathrm{CH}_{2}\right), 29.5\left(\mathrm{C}-17, \mathrm{CH}_{2}\right), 29.0(\mathrm{C}-18$, $\left.\mathrm{CH}_{2}\right), 22.0\left(\mathrm{C}-19, \mathrm{CH}_{2}\right), 14.8\left(\mathrm{C}-20, \mathrm{CH}_{3}\right), 155.0(\mathrm{C}-21, \mathrm{C})$.

Cytosporin $\mathrm{C}(\mathbf{6})$ : tentative assignment ( $\delta$ in ppm, $\mathrm{CDCl}_{3}$ ) of the reported carbon values ${ }^{9}: 77.2$ (C-2), 74.3 (C-3), 35.5 (C-4), 57.8 (C-5), 62.4 (C-6), 55.8 (C-7), 157.7 (C-8), 129.9 (C-9), 68.9 (C-10), 16.0 (C-11), 27.8 (C-12), 189.7 (C-13), 31.6 (C-14), 29.9 (C-15), 29.1 (C-16), 22.3 (C-17), 13.9 (C-18).

Compound 1a. $1 \mathrm{mg}$ of cytosporin $\mathrm{D}(\mathbf{1})$ was dissolved in anhydrous $\mathrm{CH}_{2} \mathrm{Cl}_{2}(0.5 \mathrm{~mL})$ with catalytic amount of DMAP and $10 \mu \mathrm{L}$ of acetic anhydride was added to this solution. The reaction was stirred overnight at room temperature. $\mathrm{CH}_{2} \mathrm{Cl}_{2}$ was removed in vacuo and the residue was worked as usual to afford pure $1 \mathrm{a}(0.7 \mathrm{mg}) ; \mathrm{R}_{f} 0.9\left(\mathrm{CHCl}_{3} / \mathrm{CH}_{3} \mathrm{OH}, 98: 2\right)$; selected ${ }^{1} \mathrm{H}-\mathrm{NMR}$ signals: $\delta 6.00(\mathrm{H}-7), \delta 4.85(\mathrm{H}-3), \delta 4.85-4.70\left(\mathrm{H}_{2}-13\right), \delta 2.12(3 \mathrm{H}$, $\left.\mathrm{CH}_{3} \mathrm{CO}-13\right), \delta 2.06\left(6 \mathrm{H}, \mathrm{CH}_{3} \mathrm{CO}-3\right.$ and $\left.\mathrm{CH}_{3} \mathrm{CO}-7\right)$. ESIMS: $\mathrm{m} / \mathrm{z} 465(\mathrm{M}+\mathrm{H}), 405(\mathrm{M}-60+\mathrm{H})$, $345(\mathrm{M}-2 \times 60+\mathrm{H}), 285(\mathrm{M}-3 \times 60+\mathrm{H})$.

Compound 1b: $5.0 \mathrm{mg}$ of compound $1(0.015 \mathrm{mM})$ was stirred in anhydrous $\mathrm{CH}_{2} \mathrm{Cl}_{2}(1 \mathrm{~mL})$ catalytic amount of DMAP and $5.0 \mathrm{mg}$ of 4,4'-dimethoxytrytil chloride (0.015mM, DMT) for $2 \mathrm{~h}$ at room temperature. $\mathrm{CH}_{2} \mathrm{Cl}_{2}$ was removed in vacuo and the reaction mixture was purified by chromatography in a Pasteur pipette $\left(\mathrm{SiO}_{2}, \mathrm{CHCl}_{3}\right) .{ }^{1} \mathrm{H}-$ and ${ }^{13} \mathrm{C}-\mathrm{NMR}$ data in $\mathrm{CD}_{3} \mathrm{OD}(\delta$ in ppm, $J$ in Hz): 3.66 (H-3, dd, 12.8, 4.1), 2.24 (H-4ax, t, 12.8), 1.64 (H-4eq, dd, 12.8, 4.1), 3.26 (H-6, br s), 4.63 (H-7, br s), 4.51 (H-10, br s), $1.29\left(\mathrm{H}_{3}-11, \mathrm{~s}\right), 1.30\left(\mathrm{H}_{3}-12, \mathrm{~s}\right), 3.66(\mathrm{H}-$ 13a, d, 10.8), 3.80 (H-13b, d, 10.8), 6.04 (H-14, m), 6.03 (H-15, m), $2.07\left(\mathrm{H}_{2}-16, \mathrm{~m}\right), 1.35$ $\left(\mathrm{H}_{2}-17, \mathrm{~m}\right), 1.40\left(\mathrm{H}_{2}-18, \mathrm{~m}\right), 1.30\left(\mathrm{H}_{2}-19, \mathrm{~m}\right), 0.93\left(\mathrm{H}_{3}-20, \mathrm{t}, 6.8\right), 6.84-7.52(\mathrm{Ar}-\mathrm{H}, 13 \mathrm{H})$, 
$3.80\left(\mathrm{OCH}_{3}, \mathrm{~s}, 6 \mathrm{H}\right) ; 77.9(\mathrm{C}-2, \mathrm{C}), 73.9(\mathrm{C}-3, \mathrm{CH}), 36.5\left(\mathrm{C}-4, \mathrm{CH}_{2}\right), 57.5(\mathrm{C}-5, \mathrm{C}), 61.6(\mathrm{C}-6$, $\mathrm{CH}), 65.1(\mathrm{C}-7, \mathrm{CH}), 134.4(\mathrm{C}-8, \mathrm{C}), 130.0(\mathrm{C}-9, \mathrm{C}), 68.6(\mathrm{C}-10, \mathrm{CH}), 16.4\left(\mathrm{C}-11, \mathrm{CH}_{3}\right)$, $27.9\left(\mathrm{C}-12, \mathrm{CH}_{3}\right), 61.2\left(\mathrm{C}-13, \mathrm{CH}_{2}\right), 127.8(\mathrm{C}-14, \mathrm{CH}), 135.3(\mathrm{C}-15, \mathrm{CH}), 34.3\left(\mathrm{C}-16, \mathrm{CH}_{2}\right)$, $30.7\left(\mathrm{C}-17, \mathrm{CH}_{2}\right), 32.4\left(\mathrm{C}-18, \mathrm{CH}_{2}\right), 23.0\left(\mathrm{C}-19, \mathrm{CH}_{2}\right), 14.4\left(\mathrm{C}-20, \mathrm{CH}_{3}\right), 55.7\left(\mathrm{OCH}_{3}\right)$, 114.0-158.0 (Ar).

Compound 1c ( $S$-MTPA-ester): the compound was prepared by treating $2 \mathrm{mg}$ of $\mathbf{1 b}$ with $0.005 \mathrm{~mL}$ of $R$-(-)-MTPA chloride in dry $\mathrm{CH}_{2} \mathrm{Cl}_{2}(0.5 \mathrm{~mL})$ with catalytic amount of DMAP under stirring for $16 \mathrm{~h}$ at room temperature. The ester was purified by chromatography in a Pasteur pipette $\left(\mathrm{SiO}_{2}, \mathrm{CHCl}_{3}\right)$. Selected ${ }^{1} \mathrm{H}$ NMR values are in Table 2.

Compound 1d ( $R$-MTPA-ester): the compound was prepared by treating $2 \mathrm{mg}$ of $\mathbf{1 b}$ with $0.005 \mathrm{~mL}$ of $S$-(-)-MTPA chloride in dry $\mathrm{CH}_{2} \mathrm{Cl}_{2}(0.5 \mathrm{~mL})$ with catalytic amount of DMAP under stirring for $16 \mathrm{~h}$ at room temperature. The ester was purified by chromatography in a Pasteur pipette $\left(\mathrm{SiO}_{2}, \mathrm{CHCl}_{3}\right)$. Selected ${ }^{1} \mathrm{H}$ NMR values are in Table 2.

Compound 2a. $1 \mathrm{mg}$ of cytosporin $\mathrm{E}$ (2) was dissolved in anhydrous $\mathrm{CH}_{2} \mathrm{Cl}_{2}(0.5 \mathrm{~mL})$ with catalytic amount of DMAP and $10 \mu \mathrm{L}$ of acetic anhydride was added to this solution. The reaction was stirred overnight at room temperature. $\mathrm{CH}_{2} \mathrm{Cl}_{2}$ was removed in vacuo and the residue was worked as usual to afford pure 2a $(0.9 \mathrm{mg}), \mathrm{R}_{f} 0.5\left(\mathrm{CHCl}_{3} / \mathrm{CH}_{3} \mathrm{OH}, 95: 5\right)$; selected ${ }^{1} \mathrm{H}-\mathrm{NMR}$ signals $\left(\mathrm{CD}_{3} \mathrm{OD}, \delta\right.$ in ppm): $\delta 5.25(\mathrm{H}-3), \delta 4.95-4.82\left(\mathrm{H}_{2}-13\right), \delta 2.08$ and $2.10\left(6 \mathrm{H}, \mathrm{CH}_{3} \mathrm{CO}-3\right.$ and $\left.\mathrm{CH}_{3} \mathrm{CO}-13\right)$. ESIMS: $m / z 489(\mathrm{M}+\mathrm{Na}), 407(\mathrm{M}-60+\mathrm{H})$.

${ }^{1} \mathrm{H}$ - and ${ }^{13} \mathrm{C}-\mathrm{NMR}$ assignments in DMSO-d $\mathrm{d}_{6}(\delta$ in ppm, $J$ in $\mathrm{Hz}): 5.03(\mathrm{H}-3, \mathrm{dd}, 11.8,5.7)$, 2.25 (H-4eq, dd, 11.8, 5.7), 1.84 (H-4ax, t, 11.8), 4.78 (H-6, d, 7.5), 5.60 (H-7, d, 7.5), 4.00 (H-10, br s), $1.23\left(\mathrm{H}_{3}-11, \mathrm{~s}\right), 1.02\left(\mathrm{H}_{3}-12, \mathrm{~s}\right), 4.82$ (H-13a, d, 13.5), 4.70 (H-13b, d, 13.5), 6.45 (H-14, d, 15.8), 6.02, (H-15, m,), $2.18\left(\mathrm{H}_{2}-16, \mathrm{~m}\right), 1.40\left(\mathrm{H}_{2}-17, \mathrm{~m}\right), 1.22\left(\mathrm{H}_{2}-18, \mathrm{~m}\right)$, $1.30\left(\mathrm{H}_{2}-19, \mathrm{~m}\right), 0.88\left(\mathrm{H}_{3}-20, \mathrm{t}, 6.6\right), 5.60(\mathrm{OH}-5, \mathrm{~s}), 2.03\left(\mathrm{COCH}_{3}-3, \mathrm{~s}\right), 2.01\left(\mathrm{COCH}_{3}-13, \mathrm{~s}\right)$; 75.0 (C-2, C), 72.3 (C-3, CH), $37.5\left(\mathrm{C}-4, \mathrm{CH}_{2}\right), 67.0$ (C-5, C), $79.0(\mathrm{C}-6, \mathrm{CH}), 74.3$ (C-7, $\mathrm{CH}), 130.0(\mathrm{C}-8, \mathrm{C}), 132.0(\mathrm{C}-9, \mathrm{C}), 69.2(\mathrm{C}-10, \mathrm{CH}), 16.5\left(\mathrm{C}-11, \mathrm{CH}_{3}\right), 27.7\left(\mathrm{C}-12, \mathrm{CH}_{3}\right)$, $61.0\left(\mathrm{C}-13, \mathrm{CH}_{2}\right), 124.0(\mathrm{C}-14, \mathrm{CH}), 135.5(\mathrm{C}-15, \mathrm{CH}), 32.9\left(\mathrm{C}-16, \mathrm{CH}_{2}\right), 28.2\left(\mathrm{C}-17, \mathrm{CH}_{2}\right)$, 
$30.2\left(\mathrm{C}-18, \mathrm{CH}_{2}\right), 21.9\left(\mathrm{C}-19, \mathrm{CH}_{2}\right), 14.1\left(\mathrm{C}-20, \mathrm{CH}_{3}\right), 154.2(\mathrm{C}-21, \mathrm{C}), 170.0\left(\mathrm{COCH}_{3}-3\right.$ and $\left.\underline{\mathrm{COCH}}_{3}-13, \mathrm{C}\right), 21.5\left(\mathrm{COC}_{3}-3\right.$ and $\left.\mathrm{COCH}_{3}-13, \mathrm{C}\right)$.

\section{Acknowledgements}

The authors thank ICB personnel: Mrs. Ricciardi D. for technical support, Mr. Turco R. for artwork and Mrs. Melck D. for biological assays. Dr. de Cock of CBS and Dr. Ricelli A. of ICB (branch of Rome) are gratefully acknowledged for the taxonomy of E. scoparia and for valuable discussion, respectively. This work was partially supported by the Italian-Chinese bilateral project CNR-CAS "Chemical studies on bioactive molecules with biotechnological interest from Chinese marine invertebrates".

\section{References}

1. Jensen, P. R.; Fenical, W. "Marine microorganisms and Drug discovery: Current status and Future potential" in Drugs from the sea; N. Fusetani, Ed.; Tokio, 2000; pp 6-29.

2. Bugni, T. S.; Ireland, C. M. Nat Prod. Rep., 2004, 21, 143-163.

3. Saleem, M.; Shaiq Ali, M.; Hussain, S.; Jabbar, A.; Ashraf, M.; Lee, Y.S. Nat. Prod. Rep., 2007, 24, 1142-1152.

4. Numata, A.; Iritani, M.; Yamada, T.; Minora, K.; Matsumura, E.; Yamori, T.; Tsuruo, T. Tetrahedron Lett., 1997, 38, 8215-8218.

5. Cimino, G.; Fontana, A.; Gavagnin, M. Curr. Org. Chem., 1999, 3, 327-372; Cimino, G.; Ciavatta, M.L.; Fontana, A.; Gavagnin, M. In Bioactive Natural Products: Isolation, Structure Elucidation and Biology Properties, C. Tringali, Ed.; Taylor and Francis, London, 2001; pp. 577-637; Gavagnin, M.; Ungur, N.; Mollo, E.; Templado, J.; Cimino, G. Eur. J. Org. Chem, 2002, 1500-1504; Cutignano, A.; Fontana, A.; Renzulli, L.; Cimino, G. J. Nat. Prod., 2003, 66, 1399-1401; Gavagnin, M.; Mollo, E.; Docimo, T.; Guo, Y.-W.; Cimino, G. J. Nat. Prod. 2004, 67, 2104-2107; Manzo, E.; Ciavatta, M. L.; Gavagnin, M.; Mollo, E.; Wahidulla, S.; Cimino, G. Tetrahedron Lett. 2005, 46, 465-468; Ciavatta, M. L.; 
Lopez, M. P.; Gavagnin, M.; Manzo, E.; Mollo, E.; D’Souza, L.; Cimino, G. Molecules 2006, 11, 808-816;

6. Carbone, M.; Gavagnin, M.; Amodeo, P.; Mattia, C.A.; Lotti, C.; Castelluccio, F.; Mollo, E.; Guo, Y-W.; Cimino, G. manuscript in preparation.

7. Tomoda, H.; Namatame, I.; Si, S.; Kawaguchi, K.; Madama, R.; Namikoshi, M.; Omura, S. J. Antibiot., 1999, 52 (10), 851-856; Tomoda, H.; Namatame, I.; Tabata, N.; Kawaguchi, K.; Si, S.; Omura, S. J. Antibiot., 1999, 52 (10), 857-861.

8. Jayatilake, G.S.; Thornton, M.P.; Leonard, A.C.; Grimwade, J.E.; Baker, B.J. J. Nat. Prod., 1996, 59, 293-296; Fdhila, F.; Vazquez, V.; Sanchez, J.L.; Riguera, R. J. Nat. Prod., 2003, 66, 1299-1301.

9. Stevens-Miles, S.; Goetz, M. A.; Bills, G. F.; Giacobbe, R. A.; Tracz, J. S.; Chang, R. S. L.; Mojena, M.; Martin, I.; Diez, M. T.; Pelaez, F.; Hensens, O. D.; Jones, T.; Burg, R. W.; Kong, Y. L.; Huang, L. J. of Antibiotics, 1996, 49, 119-123.

10. Diez, M.T.; Goetz, M.A.; Giacobbe, R.A.; Hensens, O.D.; Huang, L.; Martin, I.; Jones, E.T.; Stevens-Miles, S.; Kong, Y.L. Substituted hexahydrobenzopyran derivatives as angiotensin II antagonist. U.S. Patent 5,276,054, 1994.

11. a) Liu, Z.; Jensen, P. R.; Fenical, W. Phytochemistry, 2003, 64, 571-574; b) Mehta, G.; Roy, S. Org. Lett., 2004, 6, 2389-2392.

12. Davis, R. A.; Andjic, V.; Kotiw, M.; Shivas, R. G. Phytochemistry, 2005, 66, 2771-2775.

13. Ohtani, I.; Kusumi, T.; Ishitsuka, M.O.; Kakisawa, H. Tetrahedron Lett., 1989, 30, 3147-3150; Ohtani, I.; Kusumi, T.; Kashman, Y.; Kakisawa, H. J. Am. Chem. Soc., 1991, 113, 4092-4096.

14. Bergero, R.; Girlanda, M.; Varese, G.C.; Intili, D.; Luppi, A.M. Polar Biol., 1999, 21, 361-368.

15. Yuan, Z.Q. Australian Syst. Bot., 1996, 9, 337-360.

16. Pongcharoen, W.; Rukachaisirikul, V.; Phongpaichit, S.; Rungjindamai, N.; Sakayaroj, J. J. Nat.Prod., 2006, 69, 856-858. 